ESTUDOS R:EP

\title{
Historia desde el cine [y con la literatura] para la educación
}

Joan del Alcàzar

\section{Resumen}

Vivimos en un mundo en el que las imágenes conforman las distintas memorias de nuestro tiempo. El historiador, en su tarea docente, acepta esa preponderancia de las imágenes y las integra en su tarea profesional mediante el uso de lo que denominamos documentos en soporte de vídeo (DSV). Además, el docente puede (y debe) incorporar otro tipo de fuente como es la literatura, para hacer más accesible el conocimiento histórico. Por cuanto respecta al trabajo con los DSV, establecemos tres categorías entre ellos, y proponemos un abordaje en cuatro etapas: identificación, contextualización, disección y análisis. Entendemos que el trabajo con los DSV nos permite un doble plano formativo: el desarrollado por el profesor para y con los estudiantes, y el de los propios estudiantes que individualmente o en grupo abordan el análisis histórico.

Palabras clave: historia; cine; educación. 


\section{Abstract \\ History from cinema (and literature) for education}

We live in a world where images compose differents memories of our time. A historian, in his teacher task, accepts this image prevalence and integrates them in his professional duties through the use of video supporting documents. Moreover, the teacher can (and should) incorporate other kind of sources as literature in order to make the historical knowledege more accessible. Concerning the work with the video supporting documents, three categories were established, we propose a four steps approach: identification, contextualization, dissection and analysis. Considering that the work with video supporting documents enables a double formative plan: the developed by the teacher to and with the students, and the historical analysis in the students plan that can be developed individually or in group.

Keywords: history; cinema; education.

Ya hace tiempo que la sociedad actual es dependiente de las imágenes, ya sean las del cine de ficción, con mayor o menor calidad artística, ya sean las del documental, que también es creación pero no debe contener ficción. Y si la sociedad no se puede permitir vivir sin imágenes, menos aún aquellos que hacemos análisis interpretativos de los antecedentes históricos de ella. En estos momentos que vivimos, las imágenes constituyen un tipo de fuente documental imprescindible para el historiador, una fuente que está en un soporte que no es el del documento archivístico o hemerográfico tradicional, sino que la encontramos en soporte de vídeo. ${ }^{1}$

Podemos hablar de un mínimo de tres categorías entre los Documentos en Soporte de Vídeo (DSV). Aunque me gustaría poder hacer una presentación en clave exclusivamente brasileña, vamos a abrir el campo y la haremos en márgenes latinoamericanos. Más adelante, para mejor comprender el planteamiento que defendemos, nos centraremos en una cinematografía en la que hemos trabajado con cierta profundidad como es la chilena, pero con DSV que han tenido mucha repercusión internacional y por lo tanto pueden ser bien conocidos por el lector brasileño.

Digamos ahora, para abrir camino a la exposición de la tesis que sustenta nuestro texto, que el primer grupo lo constituyen aquellos DSV que son más útiles para el análisis de las sociedades en que han sido producidos que para el tema histórico que abordan: pensemos en una excelente película mexicana, como es La ley de Herodes (Luis Estrada, 1999). La acción discurre en 1949, cuando los habitantes de

\footnotetext{
${ }^{1}$ Hemos escrito antes sobre la relación entre la historiografía $\mathrm{y}$ el historiador, y lo que los directores trasladan a las pantallas. Vid., por citar el texto más reciente, Alcàzar y López Rivero (2009, especialmente las páginas 13-31).
} 
la localidad de San Pedro de los Saguaros decapitan de un machetazo a su alcalde cuando trataba de huir del pueblo con el dinero de las arcas municipales. El licenciado López, secretario del gobernador, decide nombrar a Juan Vargas, encargado de un basurero y antiguo militante del Partido Revolucionario Institucional (PRI), como nuevo alcalde hasta las próximas elecciones en las que él es firme aspirante a la gubernatura del estado. Vargas afronta su misión con las mejores intenciones, hasta que poco a poco va descubriendo los beneficios del poder y la corrupción. Se transforma así en un tirano capaz de todo, incluso de recurrir al crimen, para perpetuarse en el poder.

La película tropezó con la censura y con la proa del partido de gobierno, el PRI, ya que México todavía vivía bajo su hegemonía indiscutible aunque ya se estaba a las puertas del año electoral que fue el 2000. Sin embargo, la fuerte presión ejercida por el público - ansioso de ver una película de contenido político sin censura- y por varios medios impresos que se atrevieron a denunciar el bloqueo del cual era objeto, logró que fuera finalmente exhibida. Además de por su calidad, el film de Estrada destaca porque nos permite conocer mejor aquella sociedad sobre la que influyó. Puede considerársela como una de las grandes películas mexicanas de las últimas décadas, no solo por su calidad, sino por la influencia que tuvo sobre muchos votantes para destronar del poder al partido hegemónico al cual retrata con todos sus vicios, defectos y contradicciones.

En segundo lugar, los que abordan un hecho o un proceso histórico desde una perspectiva y con un calado que ofrece interés para el historiador, pero no son particularmente útiles para el análisis de la sociedad en que han sido creados, como, por ejemplo, Estado de sitio (C. Costa-Gavras, 1973). En el Uruguay del año 1970, un funcionario ligado a la CIA, y perteneciente a una agencia gubernamental estadounidense orientada al entrenamiento de fuerzas policiales extranjeras, Philip Michael Santore, es secuestrado por la guerrilla urbana uruguaya Movimiento de Liberación Nacional-Tupamaros (el MLN-T). Tras su interrogatorio, se condiciona su libertad ante el gobierno, a cambio de la liberación de 150 guerrilleros encarcelados. Esta situación desencadena una crisis política de trágicas consecuencias que acaba con el asesinato del norteamericano. Es una película franco-italiana, rodada en el chile de la Unidad Popular, que -lógicamente- nos aporta muy poco sobre las sociedades en las que ha sido producida, pero muchísimo en cuanto al fenómeno de la guerrilla urbana latinoamericana, a la dinámica acción-represión que caracteriza el período, y a las implicaciones internacionales de la insurgencia y de los represores de ésta.

Finalmente, los más provechosos son aquellos que sirven para el análisis del hecho o del proceso histórico sobre el que versan, y pasan a ser, también, del mayor interés para profundizar en el análisis de la sociedad que los ha producido; es el caso, por ejemplo, del film La historia oficial (Luis Puenzo, 1984). En la última etapa de la última dictadura militar argentina, una profesora de historia comienza a darse cuenta de lo acontecido en el país en los años anteriores. El retorno de una 
amiga exiliada, el descubrimiento de los turbios manejos de su esposo y la aparición de una Abuela de Plaza de Mayo que busca a su nieta son motivos más que suficientes para que la mujer viva una auténtica toma de conciencia política. La historia oficial fue el primer film argentino post dictadura en tratar con éxito la problemática política del país, y es una evidencia de la realidad de la sociedad argentina del momento, cuanto menos de la corriente dominante, que se refugia en lo que Mario Ranalletti (2009) ha llamado la teoría de los dos demonios. ${ }^{2}$ No obstante, la película tuvo un gran reconocimiento internacional, incluido el Oscar de la Academia de Hollywood al mejor film en lengua no inglesa.

Dicho lo anterior, podemos concluir que -como dice Shlomo Sand-los historiadores, a pesar de todas las dificultades que eso pueda generarnos, debemos estar atentos a los relatos del pasado que realizan el cine y la televisión, y debemos integrarlos en las discusiones y los programas de estudios (Sand, 2005, p. 504). Nosotros ampliamos el reto a los profesionales de la educación, al menos a todos aquellos que pueden utilizar el cine -en su sentido más genérico- como herramienta didáctica en las aulas.

Vivimos inmersos en un mundo de imágenes en el que la palabra, la transmisión oral del conocimiento, parece haber perdido fuerza si no la acompañamos de imágenes. No son solo los informativos de televisión los que han de ser respaldados por las imágenes; son las conferencias académicas, incluso las clases clásicas de nuestras facultades, las llamadas con demasiada ligereza magistrales, las que se han de reforzar con diapositivas de textos, mapas, cuadros, fotografías, incluso filmaciones en vídeo. Y ello responde no sólo a una moda más o menos caprichosa, sino que obedece a una lógica incontestable: nuestro mundo es un mundo de palabras e imágenes $\mathrm{y}$, por tanto, al apoyarnos en unas y otras damos a nuestro discurso solidez y, además, lo hacemos más inteligible, más didáctico.

Entre los profesionales de la historia parece que no hay dudas al respecto de la bondad de la incorporación del cine en los dos planos principales de su quehacer: la investigación y la enseñanza de la historia. ${ }^{3}$ Existe consenso respecto a la idea de que los DSV son la principal fuente de conocimiento histórico de la mayor parte de los ciudadanos de las sociedades occidentales. Unos DSV, ya sea cine de ficción ya sea cine documental, que reciben tanto desde las pantallas cinematográficas como desde la televisión y, de forma creciente, a través de Internet. ${ }^{4}$

José Florit (2004), en el prólogo a un conocido libro de José María Caparrós Lera, apuesta decididamente por el binomio cine-historia, hasta el punto que afirma que "las fronteras que separan a un historiador que obtiene con sus obras escritas un reconocimiento público amplio, que publica best-sellers, y un director de cine histórico de éxito -un Stone (con el film Nixon), por ejemplo-, no parece que tiendan a ampliarse sino, al contrario, a reducirse".

Ya hemos dicho que vivimos el triunfo de la imagen, y que hoy día, especialmente tras el cataclismo del 11-S neoyorkino que ha marcado

\footnotetext{
${ }^{2}$ Una tesis que explica el origen de la dictadura militar argentina de 1976-82 en la violencia ejercida por dos demonios situados en polos antagónicos: de un lado, grupos izquierdistas y, de otro, ultraderechistas secundados por la sangrienta represión militar que llevo a cabo el régimen. Esta explicación del proceso político posee la ventaja, correlativamente, de exculpar al grueso de la sociedad de los crímenes cometidos durante la última etapa del gobierno peronista (1974-76) y durante la dictadura (1976-83). Ver Ranalletti (1999)

${ }^{3}$ Especialmente relevante es el trabajo desarrollado por un grupo de profesores valencianos, el Grup Embolic -Ferrer, García, Hernández y Lerma-, en torno a la enseñanza de la filosofía. Es necesario destacar su obra Cinema i filosofía, de 1995. De los mismos autores es también Primum videre, deinde philosophari... de 2006. Muy importante es, finalmente, la colección Cine y Derecho, que en la editorial Tirant lo Blanch dirige el profesor de la Universitat de Valencia Javier de Lucas.

${ }^{4}$ En este texto nos referimos de manera genérica a los Documentos en Soporte de Vídeo (DSV) porque no distinguimos entre cine de ficción y cine documental, por cuanto hace a nuestro interés y a la consideración de documentos primarios que concedemos a ambos.
} 
${ }^{5}$ Cuando hablamos de memoria o de memorias estamos aludiendo a un concepto bastante novedoso, que no tiene un significado unívoco. Sin olvidar a M. Halbwachs o a A. Dupronto, debemos recordar que Enzo Traverso (2006) lo sitúa en el último cuarto del siglo pasado, mientras que en España aparece en la práctica en la década final En 1996 apareció el libro de Paloma Aguilar y en 1998 un monográfico de la revista Ayer, $n^{\circ} 32$, coordinado por Josefina Cuesta, con un monográfico dedicado a Memoria e Historia. Independientemente de que en su momento volveremos sobre esta problemática -tanto la del significado del concepto como el de su relación con la disciplina histórica-, salvo indicación en contrario cuando en este texto nos referimos a las distintas memorias respecto a los traumatismos sociales del último tercio del siglo pasado lo hacemos en el sentido de los discursos y/o de los usos políticos que se hacen de ese período. nuestra memoria, resulta impensable el cuestionamiento del cine, pero las imágenes tienen también su lado oscuro: en la era digital, con las grandes posibilidades tecnológicas de adulteración de las imágenes, con el poder que confiere la creación, la recreación o la simulación de ellas, están bajo sospecha. El problema, sin embargo, no es nuevo para el historiador: ha de ser más vigilante todavía en su permanente crítica a las fuentes.

Paralelamente, y sin que ello sea contradictorio, aunque quizá sí paradójico, las imágenes ha derribado todas las murallas que parecían obstaculizar su desarrollo hace algunas décadas. La televisión, que en los años cincuenta concitaba el desprecio de las elites y de los dirigentes, como antes había ocurrido con el cine, se ha convertido en el principal vehículo de transmisión de ideas políticas y culturales. Las imágenes penetran en el ámbito doméstico y ejercen una enorme influencia sobre las ideas, las opiniones, las costumbres, las memorias ${ }^{5}$ individuales y de grupo. Hoy día, como sostiene Ferro (1995), la televisión ha vampirizado al cine; pero, junto a él, constituye una pareja de siameses que no pueden vivir el uno sin el otro: "el cine no podría existir sin la ayuda de la televisión, y la televisión sin películas perdería el favor del público" (Ferro, 1995, p. 38). Y, cada vez más, el cine y la televisión necesitan de Internet.

Nuestras consideraciones en torno al cine son igualmente extensivas a los documentales elaborados tanto por cineastas como por profesionales de la información y destinados de forma casi exclusiva a la televisión. Coincidimos en este sentido con David Vásquez (1995) en la importancia que posee este material -el DSV, tanto cine de ficción como documentales- como eje que nos permite, adentrándonos en la memoria visual de nuestro siglo, un mejor conocimiento de nuestra historia contemporánea: en su calidad de producto cultural inmerso en un contexto histórico es, sin duda, un espejo en el que se reflejan las obsesiones, miedos y estados de ánimo de una sociedad.

Es evidente que el historiador no se acerca al film con una mirada de valoración artística, y es que no nos interpelan ni la estética ni los valores técnicos del producto cinematográfico, sino que nos interesa el
producto cultural que da fe y aporta información sobre el universo y el marco vital del autor, [porque] como toda creación cultural, contiene elementos ideológicos o políticos, cuya revelación ilumina la realidad histórica retratada. Las aspiraciones, los sueños y las creencias de muchos seres humanos hallan una vía de expresión en las producciones populares de los cineastas, e ignorar estos elementos equivaldría a privarse del conocimiento de una parte importante de la cultura del siglo XX (Sand, 2005, p. 488).

Un ejemplo paradigmático de lo que decimos en relación a la mirada con la que el historiador se acerca al producto fílmico, y de cómo ésta difiere de la del crítico cinematográfico, lo encontramos en un documental que calificamos de excepcional como es Compañero presidente (Miguel Littin, 1971). Aunque el crítico Vera-Meiggs coincide en valorarlo como documento histórico (arqueológico, dice él), le niega todo valor artístico. Tiene razón, sin duda, cuando afirma que 
Parece increíble que algo así se haya mostrado en los cines y se pensara que podría ayudar "al proceso", cuando más bien parece un castigo para todos aquellos que aun no se daban cuenta de la importancia de lo que se vivía. [...] Parece una paradoja que un diálogo intelectual así filmado pudiera servir para ganar prosélitos. Aunque tampoco pareciera servir mucho para los que ya estaban convencidos, porque para eso estaba la televisión, que siempre ha servido mejor para los debates. ${ }^{6}$

Tiene razón el crítico en que cuesta trabajo imaginar que ese documental convenció a alguien de algo que no fuera que la Vía chilena desembocaba en Cuba; y la mantiene cuando afirma que hoy día Compañero presidente es un resto arqueológico que, como tal, debe ser preservado para la futura memoria. Claro que no le vamos a discutir que el cine es una cosa, la televisión otra y la discusión política una tercera, y que "mezclarlo todo puede producir mejunjes indigestos que explican las dificultades críticas que hoy podemos tener para evaluar positivamente el cine de la Unidad Popular" ${ }^{7}$ Todo eso es muy razonable. Pero desde la mirada del historiador, desde sus intereses profesionales, Compañero presidente es un documento excepcional por la cantidad de preguntas que podemos hacerle y por la calidad de las respuestas que podemos encontrar.

Sirva lo anterior para que aclaremos que, por cuanto respecta a los DSV, podemos diferenciar, como mínimo, cuatro planos que constituyen otras tantas perspectivas de abordaje y análisis: a) el relativo a la historia del cine (su evolución, avances, técnicas, etc.); b) el de la historia de la utilización del cine (como transmisor de ideología, como fuente en el análisis de la sociedad en la que se ha producido uno o varios filmes, etc.); c) el de la utilización del cine como fuente por el historiador; y, finalmente, d) el de la utilización del cine como material didáctico en la enseñanza de la historia. Nos interesan, fundamentalmente, los tres últimos.

Respecto a la utilización del cine, ésta es una cuestión que conecta directamente con el uso de la imagen con una intención ideológica, tendencia que ha sido prácticamente una constante histórica. Desde los primeros documentales sobre la I Guerra Mundial a las superproducciones del Hollywood de la época de McCarthy o a los productos recientes de las grandes multinacionales de la época actual, ha existido una clara intencionalidad de aleccionar, controlar y conducir a la opinión pública en un sentido coincidente con el discurso dominante. Obviamente el cine, o los DSV, han sido abundantemente utilizados como propaganda más o menos explícita, más o menos sutil.

En esta línea, un caso de implicaciones estrictamente nacionales en clave latinoamericana puede ser el de la llamada Teoría de los dos demonios de Mario Ranalletti -a la que ya hemos aludido ${ }^{8}$, que estaría en la base de la inducción al olvido, un proceso que se ha visto favorecido en las pantallas, cuyas historias han cristalizado ese deseo de no remover el pasado reciente, con el objetivo de avanzar en el establecimiento de la concordia social. El grupo de DSV que cabría incluir dentro de las tesis de Ranalletti son aquellos en los que, según sus propias palabras, no se

\footnotetext{
6 VERA-MEIGSS, D. en http://www.cinechile.cl/ crit\&estud-108. Escribe el crítico: "Alguna vez se pensó que el cine era un vehículo para ciertas ideas y que de éstas dependía la validez de una obra cinematográfica. También se ha buscado en lo contrario, es decir en la forma pura. Ambas posturas extremas han producido monstruos, como diría Goya. Estamos frente a un ejemplo."

7 Ídem.

${ }^{8}$ Ver p. 648 , nota 2.
} 
${ }^{9}$ Entre los DSV utilizados por Ranalletti, podemos citar No habrá más penas ni olvidos (1983), La historia oficial (1985), La República perdida II (1986) y La noche de los lápices (1986).

${ }^{10}$ Dos de los grandes teóricos a los que todo el mundo cita, y a los que nosotros también reconocemos su magisterio, aunque discrepemos parcialmente de algunas de sus tesis centrales, son R. Rosesntone y M. Ferro. El primero establece tres formas de plasmar la historia en el cine: el film histórico como drama, una especie de ventana abierta al pasado; el film histórico como documento, en el que las imágenes sirven para ilustrar el discurso; el film histórico como experimentación, en la medida que cuestiona nuestras propias ideas sobre la historia. Ferro, por su parte, habla de: películas de reconstrucción histórica, que pueden convertirse en documentos para la historia; películas de ficción histórica, que utilizan el pasado exclusivamente como marco en el que se desarrolla la acción; películas de reconstitución histórica, que se centran en un hecho o un proceso histórico con voluntad reinterpretadora. logra trascender el marco víctimas-victimarios, ya que el cine que se elabora en la Argentina a partir de 1983 y durante varios años focaliza mayoritariamente su atención en "represores y reprimidos, en torturadores y torturados, evitando un acercamiento a la génesis de los conflictos que se muestran" (Ranalletti, 1999, p. 7). ${ }^{9}$

El tercero de los planos que planteábamos es el que atiende a la utilización del cine como fuente por el historiador, una cuestión en cuyo epicentro se produce - cada vez con menos fuerza, desde luego- el debate entre aquellos que son partidarios de concederle a aquél el status de fuente histórica y los que, desde posiciones antagónicas, se niegan a hacerlo. Al tiempo, la investigación suscita otras cuestiones adicionales de cierta importancia, como la que nos llevaría a diferenciar, con base en el tema abordado, un mínimo de tres categorías entre los DSV, tal y como ya hemos avanzado páginas atrás. ${ }^{10}$ Debemos recordar que en este texto nos referimos de manera genérica a los Documentos en Soporte de Vídeo (DSV) porque no distinguimos entre cine de ficción y cine documental. Ambos son para nosotros documentos primarios, esto es materia prima para el historiador.

William Hughes, quien ha subrayado "las ventajas de la imagen filmada como trascripción de la realidad bruta", ha afirmado, acertadamente a nuestro juicio, que la verdad del cineasta se parece más a la verdad del novelista que a la verdad del historiador, y ello porque la verdad del novelista y la del cineasta están sustentadas en opiniones, mientras que la del historiador se basa -por principios deontológicos del oficio- en hechos. No obstante, esta consideración no mengua nuestro interés por el cine como documento, antes al contrario, ya que las películas siguen siendo testimonios históricos de primer nivel. Como dice Sand (2005, p. 492):

\begin{abstract}
Habida cuenta del extraordinario consumo del gran público, que obvia lo que no se adapta a sus gustos, las películas de ficción son un indicador importante de las inclinaciones populares y de los gustos colectivos, cuyo descubrimiento permitirá escribir la historia de los tiempos modernos. Además, y precisamente gracias al carácter popular y accesible para todo el mundo, el cine de ficción podrá ser un activo privilegiado a la hora de revelar los códigos culturales y las contradicciones ideológicas que operan en la conciencia social de una época determinada, los mitos que alimentan las creencias colectivas, las maneras de pensar y las normas morales dominantes.
\end{abstract}

Es por ello que, desde la posición de aquellos que queremos trabajar la disciplina histórica, el cine constituye una fuente documental -en la línea de entender por fuente lo que desde Annales hemos entendido- a la que ni podemos ni debemos renunciar. Creemos que nuestro objetivo se centra en la interpretación histórica, para lo cual trabajamos un conjunto de textos culturales que no son la realidad sino el material para su reconstrucción (Amador, 1996, p. 115). Podemos decir, pues, que el cine es una fuente -cuanto menos, como escribiera Febvre-, en la medida que es "testimonio de una historia viva y humana, saturada de pensamiento y de acción en potencia" (Febvre, 1976, p. 29). 
Los DSV son un testimonio de su tiempo, pero no son el reflejo puro y simple de ese período. Su relevancia como documento histórico radica en que son el resultado de la realización de un colectivo profesional, no de un creador solitario (como es el novelista), que tienen el objetivo de fabricar un producto que, por estar destinado a ser consumido por millones de personas, "tendrá un indicador de su valor, un vector de las ideologías dominantes, en el sector del público que la reciba" (Sand, 2005, p. 494).

Así pues, defendemos la utilización y la validez de los filmes de ficción y de los documentales (y de la literatura, y de los testimonios orales y de los restos materiales) como herramientas de investigación y como instrumento didáctico de la Historia. El problema radica, no obstante, en qué esperamos, qué pretendemos, con su utilización.

En esta línea, creemos que la articulación de las relaciones entre cine, por un lado, e historia por otro debe plantearse sobre la base de la idea de una complementariedad no invasiva de los contornos que contribuyen a definir cada una de estas producciones culturales. Desde esta perspectiva, pensamos que los historiadores deberíamos concebir y por tanto aprovechar el cine como parte de nuestra reflexión histórica, entendiéndolo como una forma de conocimiento y de práctica social productora de identidades y de representaciones en conflicto que a su vez contiene su propia lógica, en la que el guión cinematográfico posee innumerables licencias que le están vedadas al historiador. Utilizar el cine en historia no quiere decir convertirlo en historia. Se trata de algo tan sencillo y al tiempo tan complicado para el historiador como asumir el cine simplemente como lo que es -una fuente documental-, sin violentarlo mediante su atracción a nuestros dominios. Solo así aportarán riqueza a nuestro análisis.

Estamos de acuerdo con Pilar Amador, cuando con referencia al cine señala que "la información que nos aporta la lectura de un texto fílmico concreto exige [...] el conocimiento de los códigos apropiados que permitan al investigador relacionar la información que se obtenga con objetos o sucesos pasados" (Amador, 1996, p. 115. Las imágenes ofrecen, lógicamente, lecturas diferentes de acuerdo con el referente cultural desde el que se contemplan.

Así pues, recapitulando, diremos que no nos dejamos engullir por el relativismo extremo que ha ganado adeptos en los últimos años. Realidad y ficción son dos cosas distintas, dos planos diferenciados que no deben confundir al historiador ni al espectador de cine. Y no deben confundirlo porque el profesional de la historia realiza con su trabajo una práctica interpretativa que asume la adhesión y la crítica a los procedimientos de verificación y documentación establecidos por el quehacer que caracteriza y define a la gente de nuestro oficio. Por contra, el cineasta crea, aún cuando el referente espacio-temporal de su obra pueda ser evidentemente histórico.

A partir de aquí, quizá convenga retomar la consigna de Annales, y volver a recordar que los historiadores debemos "mezclarnos con la vida", y la vida, qué duda cabe, también está en el cine. ¿Podemos ignorarlo como profesionales de la Historia? Parece indiscutible que el siglo XX ha sido 
${ }^{11}$ La Universitat de Barcelona ha sido pionera en la utilización docente del cine, en buena medida gracias al empeño y buen hacer de un conjunto de profesores dirigidos por J. M. Caparrós. En la asignatura Historia contemporánea y cine, los estudiantes deben realizar un análisis contextual sobre una película de ficción no proyectada en clase. E guión que los estudiantes han de seguir presenta siete apartados: Ficha técnico-artística; Sinopsis argumental; el Autor (director, guionista, productor); Contexto de realización de la película (político, social, cultural, económico y cinematográfico); Cronología y hechos históricos de la época tratada en la película; Valoración crítica del film desde la perspectiva histórica; y, finalmente, Bibliografía y hemerografía utilizada (Vid. Caparrós Lera, 1998, pp. 128-145). También desde la Universidad de Cádiz, el Grupo de Investigación Intrahistoria y oralidad trabaja desde hace años con el cine referido a América Latina. Cuentan con dos libros editados, de Pérez Murillo y Fernández Fernández (Coords.): La memoria filmada: América Latina a través de su cine (2002) y La memoria filmada: historia sociopolítica de América Latina a través de su cine (2009). una centuria de testimonios visuales que se han ido acumulando a lo largo de las décadas, hasta el punto que, en más de una ocasión, el episodio ha existido por la presencia de la cámara. "Es por ello que resulta complicado escribir una historia ética, política y social de este período sin recurrir sistemáticamente a las dimensiones no escritas, documentales o ficticias, del conjunto de sus representaciones culturales." (Sand, 2005, p. 495).

\section{El cine en las aulas, una imprescindible herramienta didáctica}

La bondad -incluso la necesidad, a nuestro juicio ineludible- de la utilización didáctica es, prácticamente, una evidencia. El valor de los DSV como herramienta fundamental en la formación de los estudiantes resulta indiscutible, sea cual sea su nivel, desde el básico al universitario, considerando además la educación de las nuevas generaciones en la cultura de la imagen. ${ }^{11}$ En el entorno académico y universitario hace tiempo, camino de treinta años, que venimos utilizando de forma sistemática los DSV con nuestros estudiantes de licenciatura e, incluso, de doctorado, con resultados muy positivos.

Entendemos que el trabajo con los DSV nos permiten un doble plano formativo: el desarrollado por el profesor para y con los estudiantes, y el de los propios estudiantes que individualmente o en grupo abordan el análisis histórico de un DSV. En este segundo caso, el film de ficción o el documental se convierte en una fuente primaria en manos del futuro historiador, y esa fuente primaria, sometida al rigor crítico con el que se trabaja cualquier otro tipo de fuente documental, es la que entra en diálogo con la bibliografía y, en su caso, con otras fuentes primarias para posibilitar un nuevo resultado historiográfico.

Estamos convencidos de que al utilizar el cine como recurso didáctico realizamos un replanteamiento de la tarea docente. Rompemos con la dinámica de monólogo de los medios de comunicación de masas -en los que la información se ofrece siempre interpretada-, con el fin de despertar la capacidad crítica del estudiante, llevándole a la reflexión sobre los acontecimientos vistos, para que a través del cine "sea capaz de relacionar épocas, hechos y fenómenos culturales, descubriendo las causas que los motivaron, sus consecuencias, y así pueda relativizar posturas dogmáticas" (Amador, 1996, p. 118). Además, el film de ficción o el documental tienen una fuerza extraordinaria en la comprensión de las complejidades de los fenómenos o los procesos históricos. Veamos un par de ejemplos que ilustrarán lo que decimos: dos muestras entre otras muchas que podríamos citar, que son resultado de nuestra práctica docente más reciente. Se trata de un curso sobre culturas de movilización en América Latina que hemos impartido dentro del Máster en Historia Contemporánea, desarrollado por nuestra Universidad junto a otras importantes universidades españolas; un curso en el que, como es habitual, hemos utilizado documentos de vídeo. Dos muestras, como hemos dicho, una sobre un film de ficción, otra sobre un documental de periodismo de investigación. 
El film de ficción es $O$ que é isso, companheiro, una película brasileña de 1997, dirigida por Bruno Barreto, comercializada en España con el título de 4 días de septiembre, que fue candidata al Óscar a mejor película extranjera en ese mismo año. El film se inserta en el período de la dictadura que comienza con el golpe militar de 1964 y, más concretamente, en los efectos del golpe dentro del golpe que se produce en 1968. En este período fueron muchos los jóvenes -en su mayoría estudiantes universitarios- que entraron en la clandestinidad para desarrollar la lucha armada contra la dictadura mediante el método de la guerrilla urbana. La película fue realizada a partir de un libro de título idéntico, escrito por Fernando Gabeira, uno de esos jóvenes que como miembro del Movimento Revolucionário 8 de Outubro (MR-8) participó, en septiembre de 1969, en el secuestro de Charles Elbrick, embajador de los Estados Unidos en Brasil. El secuestro de una personalidad relevante, una novedad en la época, fue una forma de presión sobre el gobierno militar para obtener la liberación de quince presos políticos de izquierdas. En ese sentido, la operación tuvo inicialmente éxito, y los presos fueron excarcelados.

Cuando en nuestras clases hablamos de la guerrilla urbana latinoamericana incidimos en dos de sus problemas más significativos, como son el aislamiento y el militarismo. Dentro del primero, insistimos en el elitismo revolucionario, el desprecio por las formas tradicionales de lucha de la izquierda clásica (presión en la calle y en el parlamento, y acción sindical potente) y las dificultades para explicar al pueblo muchas de sus acciones, especialmente las armadas. Pues bien, en $O$ que é isso, companheiro son muchas las secuencias que podemos utilizar en nuestra explicación, pero queremos seleccionar una.

El MR-8 necesita dinero para sostener económicamente a la organización y decide atracar un banco. La secuencia nos muestra a un grupo de jóvenes correctamente vestidos, como jóvenes de clase media que son, ellas y ellos, entrando en un gran banco a punta de pistola. El responsable del grupo se sube a un mostrador, encañona a los aterrorizados clientes, y les lanza un pequeño discurso con el que el MR-8 pretende explicar su acción. Mientras dos de los jóvenes se dirigen hacia la caja de la entidad, el dirigente y otros asaltantes encañonan a los clientes. Desde la altura del mostrador les dice:

\footnotetext{
Atención, esto no es un atraco. Es una expropiación revolucionaria. Nosotros estamos expropiando esta institución bancaria que apoya a esta dictadura cruel y sanguinaria. Muchos de nuestros compañeros que luchan por la libertad y la democracia están siendo brutalmente torturados en las prisiones, y ustedes de eso no saben nada. Cuéntenle a sus amigos lo que ha sucedido. Nosotros somos el Movimiento Revolucionario 8 de Octubre. ${ }^{12}$
}

¿Elitismo, aislamiento, dificultades en la explicación de las acciones? Una secuencia de un film de ficción ilustra nuestras explicaciones y nos complementa a la perfección. Un joven armado irrumpe en un banco atestado de clientes junto a otros asaltantes y mientras encañona a unas
${ }^{12}$ Trascripción del audio de la secuencia de la película $\mathrm{O}$ que é isso, companheiro, de Bruno Barreto, 1997. La secuencia está disponible en http://www.youtube. $\mathrm{com} /$ watch?v $=9$ iD9skE6l-o. 
${ }^{13}$ Trascripción del audio de la secuencia del documental Salvador Allende, de Patricio Guzmán, 2004. La secuencia está disponible en http://www.youtube.com/watch?v=OfoBabTTzlU Esa reunión en el Despacho Oval se produjo el 15 de octubre de 1970, según acredita la documentación desclasificada de la Secretaría de Estado y de la CIA, que se encuentra en el National Security Archive's Chile Documentation Project, dirigido por Peter Kornbluh. La información está recogida en Kornbluh (2004, p. 55). personas asustadas les dice, de entrada, que lo que están viviendo no es un atraco. Es una "expropiación revolucionaria", afirma. Lo que después explica carece ya de importancia y es imposible que los amenazados presten atención a su discurso. Si el banco apoya a la dictadura o si ésta tortura a los presos carece de interés para quienes se sienten en peligro, como esa anciana que abraza protectora a su nieta. El militante niega ese código universal que todos tenemos: un grupo armado entra a un banco encañonando a todo el mundo, pero el portavoz niega que eso sea lo que todo el mundo interpreta que está pasando: que están siendo víctimas de un atraco. Con acciones como esa es imposible salvar la distancia que separa a esos jóvenes revolucionarios de los ciudadanos mejor o peor acomodados a la realidad política dictatorial.

El documental de investigación es Salvador Allende, con guión y dirección del cineasta chileno Patricio Guzmán, quien estrenó este film en el Festival de Cannes en 2004. El documento narra la vida del doctor Salvador Allende, desde su nacimiento en Valparaíso hasta su muerte en el Palacio de la Moneda, el 11 de septiembre de 1973. El DSV incluye una extraordinaria secuencia en la que Guzmán entrevista a Edward M. Korry, quien fue embajador de los Estados Unidos en Santiago de Chile entre 1967 y 1971. Korry da detalles de las intrigas e injerencias del gobierno de Washington en el Chile de la Unidad Popular comandada por Allende.

El embajador es preguntado por la posición que el presidente Richard Nixon y el Secretario de Estado Henry Kissinger tenían respecto al Chile de Allende. Con la voz en off de la periodista que conduce la entrevista, se produce el siguiente diálogo:

- Periodista: "¿Qué le dijo Nixon cuando se reunió con él en la Casa Blanca?"

- Embajador Korry: "Bueno, me saludó cálidamente y le dijo a Henry [Kissinger], 'el embajador siempre nos cuenta todo tal y como es', y empezó a soltar un discurso de cinco o seis minutos sobre cómo iba a aplastar a Allende. No paraba de golpear su puño contra la mano, y [decía] que lo destruiría, que lo hundiría económicamente, que iba a exprimirlo económicamente".

- Periodista: "¿Cómo llamaba a Allende?".

- Embajador Korry: "Lo llamaba hijo de puta. Creo que también cabrón. Ese hijo de puta, ese cabrón...". ${ }^{13}$

Pocos días antes de esta reunión en Washington, el embajador Korry había tenido noticias [por medio de sus propias fuentes], de que agentes de la CIA estaban colaborando activamente con militares chilenos para propiciar un golpe de Estado que impidiera el acceso de Allende a la Presidencia de la República. El embajador ordenó a los agentes de la estación en Santiago de la Central de Inteligencia que se alejaran de los militares chilenos y envió un cablegrama a Kissinger en el que decía: "He descubierto horrorizado la existencia de una cooperación para [tachado] planear un golpe de Estado. Los militares no van a hacer un golpe de Estado para que Viaux llegue al poder, ni existe un estado general de ánimo entre el pueblo que proporcione la justificación moral necesaria". 
A continuación, Korry alertaba de las repercusiones que una acción de este tipo podría producir: "Creo que cualquier intento por nuestra parte de alentar de forma activa un golpe de Estado acabará por convertirse en un fracaso comparable al de la Bahía de Cochinos". Korry añadía que un golpe de Estado constituiría "un desastre total para Estados Unidos [...] y dañaría sobremanera los intereses que tiene la nación en toda América Latina, cuando no fuera de ésta" (Kornbluh, 2004, p. 50. En Washington no solo no hicieron el menor caso de lo que planteaba el embajador, sino que Kissinger anuló las órdenes que aquél había dado a los agentes de la CIA y éstos volvieron a contactar con los militares chilenos proclives a la intervención militar.

Cuando abordamos el tema de la llamada Vía Chilena al Socialismo la enmarcamos siempre en el contexto geopolítico de la Guerra Fría, la ponemos en relación con las tensiones entre las superpotencias y explicamos la singularidad chilena respecto a otros procesos de desafío al orden hemisférico resultante de la II Guerra Mundial, aquellos que se inspiran y alientan en la victoria de los guerrilleros de la Sierra Maestra comandados por Fidel Castro y Ernesto Che Guevara. Lógicamente, insistimos en la componente institucionalista del doctor Allende, en su reiterada propuesta de respeto a la legalidad republicana en el avance hacia el socialismo. Atendemos, también, claro está, a los acosos y desafíos que hubo de soportar el gobierno de la Unidad Popular, algunos de los más duros desde sus propias filas, e insistimos en la cerrada oposición de la Administración Nixon, ajena a cualquier sutileza política. Para Nixon y los suyos los chilenos de Allende no eran más que comunistas amigos de Moscú, y enemigos a batir. La huelga del transporte había sido propiciada y mantenida por la Central de Inteligencia Americana, y las variaciones sobre el precio internacional del cobre, el monocultivo chileno en el mercado internacional, respondían a los hilos movidos desde Washington. Pero, ¿no es ese breve diálogo con el locuaz embajador norteamericano más expresivo que todas nuestras abstracciones? O, al menos, ¿no es un complemento ideal para nuestras explicaciones?

¿Podemos renunciar, es razonable prescindir, de esos Documentos en Soporte de Vídeo en nuestras clases? Entendemos que estos documentos, que no son otra cosa, independientemente de su formato, resultan imprescindibles para una mejora sustantiva de nuestra capacidad de enseñar historia a nuestros estudiantes.

En ese quehacer docente no hacemos sino aplicar y transmitir lo que es nuestra práctica profesional como investigador. Es por ello que nuestra propuesta es utilizar todas las fuentes disponibles: fuentes documentales archivísticas, fuentes hemerográficas, fuentes materiales, fuentes audiovisuales, fuentes orales... Hacerlo -eso sí, claro-críticamente, confrontando, validando o desestimando, sistematizando, ordenando, y ello con un sólo objetivo: ofrecer una interpretación sólida sobre el proceso o el problema histórico objeto de nuestra investigación, y ello desde la convicción de que -como escribiera en más de una ocasión Eric Hobsbawm- el conocimiento histórico exige un tipo de aproximación 
${ }^{14}$ Traducción propia, que no hace honor al original en catalán.

15 "Más de treinta mil personas han desfilado frente a nosotros, las hemos visto y las hemos escuchado. Más de treinta mil personas se han atrevido a acercarse a nuestras oficinas o a responder a nuestros llamados en regiones. Y más de treinta mil veces hemos escuchado el estupor, el temor, la impotencia que aún genera la dignidad violada por agentes del Estado [...] Una cosa es presentarse a la familia después de haber sido detenido. No cuesta el alegato de inocencia y hasta cierto orgullo por haber sufrido una injusticia o el sufrimiento por una causa que se estimaba noble. Es humano también querer mostrarse altivo y no humillado. Pero descorrer el velo de la tortura, de la humillación, de la violación física y psicológica, es algo muy difícil de hacer. Incluso ante los propios cónyuges. Y ese mismo silencio comprensible fue ahondando el daño de los sufrimientos no compartidos, de las confidencias ahogadas, de aquello que preferimos poner en la estantería de las pesadillas y arrancar de los archivos de la historia. Después de mucho escuchar, aún nos cuesta imaginar: la infamia de una agresión sexual, el desprendimiento indecoroso del pudor debido a toda integridad, la agresión física repetida para arrancar pretendidas confesiones, la corriente eléctrica, los golpes simultáneos a los oídos conocidos como 'el teléfono', y ese ingenio malévolo que poseemos los humanos cuando nos ensañamos con una víctima o simplemente hacemos ostentación de nuestro poder." (Chile, 2003, pp. 7-8). acumulativa que avanza mediante la construcción, la destrucción y la reconstrucción de variadas aproximaciones a la verdad, entendida ésta como algo que, por propia naturaleza, se resiste a integrar las categorías de lo definitivo y absoluto.

Es por ello que los historiadores, los profesionales y los que aspiran a ello, y tanto más los que tenemos especial interés en la llamada historia reciente, ni podemos ni debemos hacer otra cosa que utilizar todas las fuentes -aquellas herramientas- con las que podamos contar. En alguna ocasión hemos escrito en torno a la necesidad de auxiliarnos con la literatura. Cuando en clase hemos hablado de la pobreza, de la miseria, nos hemos detenido en los informes internacionales, en las valoraciones estadísticas, en los indicadores de consumo, en la distinción entre pobreza e indigencia, en los déficits nutricionales, pero somos conscientes que no llegamos a transmitir lo que en profundidad significa la pobreza. Es por ello que nos parece adecuado utilizar un párrafo breve de Carme Riera (2000, pp. 9-10), en su novela Cap al cel obert, en el que se nos describe como huele la pobreza de una forma y con una eficacia imposibles para el historiador:

Dentro del puño apretaba todavía un pañuelo perfumado con menta y limón, sin decidirse a guardarlo por si acaso volvía a embestirlo algún olor nauseabundo. Durante todo el viaje lo había llevado incrustado en la nariz, para intentar ahorrarse los olores asquerosos de la ciudad que, sin ningún respeto por su olfato delicadísimo, invadían el coche y lo iban impregnando de pestilencias ofensivas. No le era fácil discernir si le molestaba más el mal olor de tocino putrefacto, de las aguas corruptas, la fetidez excremental o la que procedía de los habitáculos de pobreza donde los cuerpos se guarecían [...] Todavía no había podido contrarrestar ninguno de aquellos olores innobles con esencias de perfumes puesto que sólo se había topado con gentecilla insignificante, también maloliente. Los poseedores de buenos olores no solían salir de madrugada, si no era, como en su caso, por necesidades urgentes ineludibles (Riera, 2000, pp. 9-10). ${ }^{14}$

¿Cómo explicar la tortura? ¿Qué significa esa palabra? Cuando hablamos de los Informes de las Comisiones de la Verdad, ofrecemos estadísticas, número de muertos y desaparecidos, los distribuimos por franjas de edad, por sexo, por adscripción partidista o sindical. Incluso, si utilizamos algunos de los testimonios recogidos del relato que las víctimas, el horror nos invade todavía con mayor intensidad, pero aún así pensamos que no llegamos a transmitir la barbarie con la claridad, con la efectividad que encontramos en la literatura. Porque las víctimas cuentan, narran sin perder completamente el pudor, con cierta asepsia forense, y describen el dolor, el pánico y la indefensión más absoluta con las limitaciones que son comprensibles. ${ }^{15}$ Disponemos de testimonios reales en soporte de vídeo de lo que han sido violaciones a los derechos humanos más elementales, tenemos películas de ficción que en ocasiones hemos debido interrumpir en su proyección en clase ante la afectación de los estudiantes (Garaje Olimpo o La noche de los lápices, por ejemplo). Pero la literatura es otra cosa. Leamos el fragmento de la novela de Arturo Fontaine La vida doble, 
en el que con el más degradado y soez español de Chile, la detenida narra su sesión de tortura. En este fragmento, el autor intercala los monólogos, las amenazas, las maldiciones, los insultos y el trato vejatorio inhumano de los torturadores. Además, el lector escucha en su interior los gritos de quien se considera dueño del cuerpo y de la vida de la detenida, y siente el frío y el dolor de la uña que rasga su intimidad, algo que con mucha dificultad podrá encontrar en los testimonios casi periciales de los torturados ante las Comisiones de la Verdad: ${ }^{16}$

Yo me desnudé en silencio obediente y hacía frío, un frío húmedo de lugar encerrado. Y naiden sabe que estái aquí, ¿vai cachando, conchaetumare? Yo tiritaba de frío y miedo hecha una perrita. Ya pu maraca meá, no nos huevís, y me ataron y hasta cuándo jodís, puta pringá, y me ataron y me pusieron de nuevo en la boca esa venda de tela gruesa y hedionda, y tú ya cachai, pu chuchaetumare de qué se trata, ¿o sói caís del catre?, ¿querís que te rompamos la raja con el culo de una botella quebrá?, y me afeitaron y me toqueteaban hurgando, sin deseo, y más encima seca la pulguienta, y riéndose con unas carcajadas duras y burlonas, tan remala pa la cacha que ha de ser esta huesúa sin gusto a ná, que no dan ni ganas por lo puro murienta y mala pu que es la hueona reculiá, y como quien le examina la dentadura a un caballo para saber su edad. ¿Qué se te hicieron las tetas, maraca? Más carcajadas. ¿Y no era ésta la que decían que estaba requeterrica, ricaepartirlaconluña, ah? Fue un roce áspero, brusco y doloroso, como si me desgajara, fue una apropiación agobiante a la que no opuse la menor resistencia. Después me llegó un golpe en el estómago con la cacha de una pistola. Ya pu, mierdosa. Por lo menos te gustará el aire, hija e puta. Me quedé sin aire mucho rato. Lo demás fue atravesar un túnel de dolores rápidos, agudos, insoportables, una travesía espantosa y oscura. (Fontaine, 2010, pp. 139-140).

El testimonio de esta víctima de la tortura nos adentra en el sufrimiento intensísimo, tanto físico como psíquico, de los detenidos por los cuerpos represivos de la dictadura, y nos confirma el contenido del concepto de víctima. Pero, ¿cómo explicamos quiénes son las víctimas de la dictadura militar chilena? ¿Son sólo los detenidos, los torturados, los asesinados, los desaparecidos, los exiliados, los que padecieron los rigores del insilio? Cuando los contabilizamos, los clasificamos por sexo, por edad, por profesión, por militancia política ¿no nos quedamos estrictamente en lo cuantitativo?

En el DSV Fernando ha vuelto (Silvio Caiozzi, 1998), se nos explica el trabajo que se ha realizado en la Oficina de Identificación del Instituto Médico Legal de Santiago, con los restos de un hombre que fueron encontrados, junto a muchos otros, en el Patio 29 del Cementerio General de Santiago en 1991. Los restos resultan ser -según nos explican de manera prolija- los de Fernando Olivares Mori, un joven de 27 años de edad, funcionario de Celade, un organismo de las Naciones Unidas, desaparecido desde el 5 de Octubre de 1973. Tras cuatro años de trabajo se ha logrado establecer fehacientemente la identidad de Fernando y el documental es testigo del impacto que el retorno de los restos de éste causa en su familia: su viuda, su hijo, sus hermanos y su madre. ${ }^{17}$ Particularmente importante es la figura de la madre, una mujer que sufrió
${ }^{16}$ Hemos escuchado alguna lectura dramatizada de testimonios de detenidos y entonces sí, el horror que nos ha generado es comparable al producido por la literatura.

${ }^{17}$ Vid. < http://www.cinechile.cl/ pelicula-335 $>$. 
una embolia a raíz de la desaparición del hijo, que la dejó privada. Ahora, cuando van a devolverle los restos de su hijo a casa, cuando van a realizarse las honras fúnebres, su nieto, el hijo de Fernando Olivares, quien no conoció a su padre, pregunta a la cámara si su abuela es o no una víctima de la dictadura. ¿Cómo atender a este tipo de víctima desde parámetros cuantitativos?

Lo que significó la represión, lo que las violaciones de los derechos humanos fueron como política conscientemente diseñada y aplicada por la dictadura, y lo que es más, sus efectos posteriores, incluso los familiares, los sociales, los económicos, como si de un accidente nuclear se tratara; una catástrofe que ha dejado una contaminación que no desaparece con la salida de los militares del poder, lo encontramos también en la literatura. Un soberbio ejemplo es Una casa vacía, novela de Carlos Cerda (Cerda, 1996). ${ }^{18}$

En la novela de Cerda, una pareja que atraviesa una crisis matrimonial aguda adquiere a un precio irrisorio, gracias a los contactos del padre de ella, una casa abandonada durante años. Una casa que, tras mucho trabajo y esfuerzo, volverá a ser un lugar hermoso y acogedor en el que la pareja -Manuel y Cecilia- pretenden encontrar la oportunidad para salvar su relación y empezar de nuevo. La inauguración de la nueva casa, la casa restaurada, propicia la reunión de la pareja con sus amistades más próximas:

[...] todo ocurrió justamente en el mismo espacio en el que ahora está el grupo de amigos, en esa casa que durante un tiempo estuvo vacía, pero en cuyo interior una serie de voces nunca dejaron de resonar hasta que el destino quiso que Cecilia las oyera ("Pero sabía también que esas voces estuvieron ahí antes del oído. Estuvieron ahí porque el dolor estuvo ahí". (Cerda, 1996, p. 323).

A partir de ahí, con el testimonio de Sergio -el hermano de Andrés, uno de los principales protagonistas de la historia- nos adentramos en la historia reciente de la posesión y el uso dado a la casa. Todo se precipitó en un aluvión de datos que finalmente proporcionaron una certeza bien amarga: la casa había sido arrendada por agentes de la DINA, que la habían utilizado como escenario de las más terribles torturas -de ahí su estado y lo que ahora se identificaba claramente como las huellas del horror. Y Sergio lo supo, en su momento, y no denunció el hecho. A continuación la casa pasó a ser propiedad del padre de Cecilia, cuyos negocios inmobiliarios consistían en gran parte en la reventa muy lucrativa de casas que hubieran sido utilizadas para esos menesteres, una vez restauradas. Y a partir de ahí, ya todos conocemos la historia: la casa pasó a manos de Cecilia y Manuel.

La novela es el instrumento que hace posible que oigamos esas voces que, aunque emanadas del territorio de la ficción, son indiscutiblemente

18 Hace años escribimos sobre ella junto a Eliseo Valle, quien antes había realizado su tesis doctoral sobre el tema. humanas y desgraciadamente similares a otras voces, las de aquellos torturados cuya existencia ha sido tristemente constatada por la historia, tanto en Chile como en otros países del Cono Sur que han sufrido 
episodios políticos semejantes. El propio autor reconoce la importancia de la escritura como conducto que hace aflorar, hasta nuestros oídos, los sonidos del dolor -"En esta novela lo que prima es el deseo de acercarme al dolor de quienes más lo han padecido, sufrirlo con ellos y darle expresión" (Cárdenas, 1996, p. 2)-, una preocupación que comparte con el narrador de la casa vacía, a tenor de las últimas palabras pronunciadas por éste -"Si no hay oídos para el dolor, no hay oídos verdaderos para nada" (Guerrero del Río, 1996, p. 47).

La literatura nos permite, entendemos, llegar al fondo de los personajes, en la medida en que éstos, a diferencia de los seres reales, se nos muestran en un modo tal que nos faculta variados prismas de acceso al conocimiento de los mismos. Nos revelan en voz alta sus pensamientos y frustraciones, sus miedos y obsesiones, confesándonos cuestiones de una manera en la que jamás lo harían nuestros semejantes, personas de carne y hueso. Cerda (1996), además, en el diseño de esta novela, ha seleccionado unos personajes que se encuentran absolutamente atrapados por el pasado reciente de su país, cuyos acontecimientos les han afectado profundamente en carne propia, hasta el punto en que a duras penas pueden arrancar de sí mismos la memoria para poder evadirse de una Historia que les ha dañado, marcándolos para siempre.

El texto de Cerda nos permite captar la atmósfera, ese aire que los personajes respiran, en tantas ocasiones viciado por las graves violaciones de derechos humanos que han sido comunes a varias dictaduras latinoamericanas y que con el paso del tiempo nos pueden resultar hasta inverosímiles... El lado oscuro de Chile aparece maravillosamente retratado, gracias a la eficacia que tiene la palabra en literatura, y así las páginas de Una casa vacía sitúan ante nosotros la vía directa de acceso a territorios intransitados, sombríos, presentes en nuestro interior y a los que la luz de la ficción llega a través del acto de lectura a iluminar: una sociedad escindida y dividida entre grupos formados por víctimas más o menos directas y torturadores o colaboracionistas más o menos activos, abriéndonos con ello un camino de comprensión de los hechos acaecidos que un texto histórico jamás alcanzaría con la misma intensidad.

Nos parece evidente que cualquier historiador profesionalmente interesado por el Chile reciente debiera leer con detenimiento la novela de Carlos Cerda y ver en profundidad la película de Ricardo Larraín, La Frontera, por no citar más. No va a encontrar en ninguno de los dos productos, el fílmico y el literario, datos, fechas, nombres, informes... No va a encontrar una información homologable a la que puede hallar en un archivo convencional. Sin embargo, su comprensión global del proceso histórico chileno de las tres últimas décadas se enriquecerá de una forma que jamás conseguiría en la soledad supuestamente aséptica de los archivos; y es que el universo literario, presente en novelas y en películas, es capaz de plasmar y alcanzar el imaginario de las sociedades que retrata y el de nosotros mismos, destinatarios de la obra de ficción.

La narrativa y la filmografía chilena han sido e indudablemente siguen siendo una manera de acercarnos a la historia de aquel país, como 
instrumentos insustituibles capaces de ayudarnos a los profesionales de la historia y a cualquiera que pretenda conocer el devenir reciente del país andino. Sabemos que no estamos descubriendo ningún mediterráneo, que quede claro: "¿Acaso no nos dan las narraciones de Tolstoi más elementos para comprender el pasado que los relatos de los historiadores, más precisos a la hora de narrar los hechos pero que pecan de una escasa comprensión de la lógica histórica?" (Sand, 2005, p. 498).

La respuesta a la pregunta, claro, alude al diferente compromiso del literato y el historiador, ya que mientras que el primero puede tomarse las libertades que mejor considere en la recreación de la realidad, al profesional de la historia "se le juzgará por la veracidad de cada sentencia formulada, y la ausencia de autenticación de sus fuentes lo desacreditará" (ídem).

La Frontera -que ya ha sido citada en páginas anteriores- es un film chileno-español de 1991, dirigido por Ricardo Larraín, que hemos utilizado con fines didácticos en nuestras clases. Su argumento es sencillo: en el Chile de 1985, un profesor de matemáticas de la Universidad de Santiago es desterrado, como castigo por haber firmado una denuncia por el secuestro y desaparición de un compañero, al profundo sur del país. Una vez allí, el profesor se aloja en la iglesia del lugar, que le da cobijo gracias a una carta del arzobispado de Santiago que lleva consigo. Una serie de personajes pueblan el lugar y dotan a la historia de unos caracteres metafóricos en relación con la realidad chilena de los últimos años de la dictadura de Pinochet.

El personaje principal es confinado en un territorio absolutamente alejado tanto de la civilización como del centro neurálgico de la dictadura, al que sin embargo alcanza el régimen a través de la figura del Delegado, así como del halo de tristeza, de frustración y de impotencia frente a la dictadura militar que se advierte en la atmósfera del film. Pese a que el profesor no es un preso, sino un desterrado, el trato que recibe por parte de las principales figuras del pueblo le obliga a explicar y esclarecer constantemente su condición, tanto ante las autoridades como ante la comunidad. Entre aquellas, y en particular, destaca la ya aludida figura del Delegado, cacique local y símbolo de la extensión de la dictadura hasta los últimos y más recónditos rincones del país. En todo momento parece seguir órdenes estrictas de la autoridad superior, mostrándose incapaz de adoptar una postura autónoma y un comportamiento razonable. Por el contrario, a lo largo de la película lo vemos desplegando una voluntad de control total que le lleva a ejercer su poder de un modo autoritario y personalista.

Si la literatura nos permite esas pincelas magistrales como las de Riera, Cerda o Fontaine, el cine, los DSV, como los de Barreto, Guzmán o Larraín, son materia prima para el docente en el aula. Con el cine, de ficción o documental, nuestro patrón de trabajo se basa en un método que no es sino una adaptación libre aunque enriquecida al análisis de los DSV de la técnica del comentario de texto histórico, lo que lleva a nuestros estudiantes a enfrentarse con ellos desarrollando cuatro fases sucesivas. Son las siguientes: 
1. Identificación del documento. Se debe realizar una ficha técnica, así como un breve resumen del argumento, información sobre la filmografía, en el caso de los filmes o los DSV, en la que se integra (el cinema novo brasileño, el llamado cine de Allende, el nuevo cine latinoamericano, la cinematografía de la Cuba castrista, el cinema de Hollywood, etc.), situando tanto el producto como a sus artífices en un contexto más amplio. Todo es importante, la figura del director y del guionista, el contexto del estreno, las críticas recibidas, los premios en su caso, la literatura que ha generado, su resultado comercial, es decir el éxito o el fracaso de la película en taquilla. ${ }^{19}$ Es importante no olvidar que nuestro interés no se sitúa en la órbita de la historia del cine -en el mejor de los casos hablaríamos de la historia de la película-, sino que pretendemos reunir la mayor información posible respecto a la fuente desde la convicción que ello nos permitirá posicionarnos con la mayor capacidad crítica ante ella.

2. Contextualización histórica del problema central del documento. Ésta debe ser construida a partir de la bibliografía previamente seleccionada. Se trata de realizar una síntesis histórica, en formato académico, sobre el problema o el proceso histórico abordado en el DSV. El conocimiento que seamos capaces de acumular, junto a la información recogida en la fase anterior, será la que nos permitirá interrogar, hacer preguntas al documento, para así profundizar en un mejor conocimiento que nos permita realizar una nueva aportación historiográfica.

3. Disección del documento. Debe procederse a la identificación clara de los distintos bloques de problemas, principales y secundarios, de forma previa a proceder a su interpretación. Esta tarea comprende el registro de los momentos o las secuencias a las que hay que prestar especial atención, así como la selección de aquellas citas textuales del narrador o de los protagonistas, susceptibles en convertirse en -digámoslo así- documentos de texto en soporte de papel susceptibles de ser analizados.

4. Estudio del texto central del análisis. Este es el objetivo final de nuestro trabajo con el DSV. Pretendemos hacer una aportación, por modesta que ésta sea, al conocimiento sobre el objeto de estudio que estamos trabajando. Es por ello que el documento en soporte de vídeo nos servirá de fundamento y base para hacer un balance general, relacionando el contenido de aquello que se ha abordado en la disección con la situación concreta a la que aquel alude. Se trataría de ofrecer una explicación razonada del tema histórico, incorporando así mismo todo aquello pertinente que resulte de la bibliografía utilizada, pero siempre en relación con lo que el propio documento nos ha suministrado.

Entendemos que nuestra propuesta permite a los estudiantes desarrollar no sólo las destrezas que son propias del oficio, sino adentrarse
${ }^{19}$ José Florit (2004, p. 11) apunta con acierto que "el éxito o fracaso de público de un film nos dice mucho sobre la opinión pública dominante en el momento en que se produce". 
${ }^{20}$ Existen esquemas distintos para enfrentarse al análisis de un DSV, pero la mayoría tienen, lógicamente, un parecido de familia. No obstante hay diferencias. Por ejemplo, José María Caparrós agrupa las películas por épocas y propone lo que él también denomina contextualización. En su caso se trata de un texto relativo "no al período 'ilustrado' o evocado", sino referido a los años en que ha sido producida la película, "haciendo hincapié en las incidencias que pudieron influir en su realización" (Caparrós Lera, 2004, p. 30). Caparrós añade otras etapas que son, tras la Contextualización, la Ficha técnico-artística, la Sinopsis argumental y la Valoración crítica. A la primer fase, le añade Films complementarios, Bibliografía y Cronología esencial (Caparrós Lera, 2004 pp. 30-31. María Dolores Pérez Murillo, en La memoria filmada: historia sociopolítica..., (Perez Murillo, Fernández Fernández, 2009) propone cuatro fases en el análisis de los films: 1) Ficha técnica; 2) Comentario personal [sic] sobre secuencias; 3) Análisis del contexto socio histórico; y, 4) Bibliografía específica sobre la problemática socio histórica. así en la comprensión del fenómeno o del proceso histórico tratado en el $\mathrm{DSV}^{20}{ }^{20} \mathrm{Y}$ estamos convencidos que -en sintonía con nuestra propuestala utilización del cine [y de la literatura] solo puede reportar beneficios al proceso educativo de nuestros jóvenes, independientemente del nivel formativo en el que se encuentren.

\section{Referências bibliográficas}

AGUILAR, Paloma. Memória y olvido de la guerra civil española. Madrid: Alianza, 1996.

ALCÀZAR, J.; LÓPEZ RIVERO, S. De compañero a contrarrevolucionário: la revolución cubana y el cine de Tomás Gutiérrez Alea. Valencia: PUV, 2009.

AMADOR, Pilar. El cine como documento social: una propuesta de análisis. Ayer, Madrid, n. 24, p. 115, 1996.

AYER. Madrid: Marcial Pons, n. 32, 1998.

CAPARRÓS LERA, J. M. 100 películas sobre historia contemporánea. Madrid: Alianza, 2004.

. La guerra de Vietnam, entre la historia y el cine. Barcelona: Ariel, 1998.

CARDENAS, Maria Teresa. Escribir desde La Compasión. Revista de Libros de El Mercurio, Santiago, n. 396, p. 2, 7 dic. 1996.

CERDA, Carlos. Una casa vacía. Madrid: Alfaguara, 1996.

CHILE. Comisión Nacional sobre Prisión Política y Tortura. Sínteses Informes. Presentación. 2003.

COMPAÑERO presidente. Dirección: Miguel Littin. Guión: Sergio Trabucco. Reparto: Salvador Allende. Chile: Chile Films. 1971. 65 min.

ESTADO de sitio. Dirección: Costa-Gavras. Producción: Jacques Henri Barratier; León Sanz; Jacques Perrin. Guion: Franco Solinas. Música: Mikis Theodorakis. Protagonistas: Yves Montand; Renato Salvatori; O. E. Hasse; Jacques Weber; Yvette Etiévant. Sonido: Michèle Boëhm; André Hervée; Jacques Maumont. Fotografía: Pierre-William Glenn. Montaje: Françoise Bonnot. Género: Drama-thriller político. Francia, Italia, Alemania. 1972. 115 min. 
FEBVRE et al. Combats per la Historia. Barcelona: Planeta, 1976.

FERNANDO ha vuelto. Dirección: Silvio Caiozzi. Producción Ejecutiva: Guadalupe Bornard. Cámara: David Bravo; Silvio Caiozzi; Nelson Fuentes. Sonido: Iván Osnovikoff; Bettina Perut. Edición: Silvio Caiozzi. Chile, 1998. $31 \mathrm{~min}$.

FERRER et al. Cinema i filosofia: com ensenyar filosofia amb l'ajut del cinema. Barcelona: La Mangrana, 1995.

. Primun videre, deinde philosophari: una historia de la filosofia a través del cine. Valencia: Institución Alfons el Magnànim, 2006.

FERRO, Marc. História contemporánea y cine. Barcelona: Ariel, 1945.

FLORIT, José. Prólogo. In: CAPARRÓS LERA, J. M. 100 películas sobre historia contemporánea. Madrid: Alianza, 2004.

FONTAINE, Arturo. La vida doble. Barcelona: Tusquets, 2010.

FRONTERA (La). Dirección: Ricardo Larraín. Guión: Ricardo Larraín; Jorge Goldemberg. Reparto: Patricio Contreras; Gloria Laso; Hector Noguera; Alonso Venegas; Aldo Bernales; Sergio Smith; Patricio Bunster; Aníbal Reyna; Sergio Hernandez; Elsa Poblete; Sergio Madrid; Joaquín Velasco; Eugenio Morales. Fotografía: Héctor Ríos. Música: Marcos de Aguirre. Chile, 1990. 120 min.

GARAJE Olimpo. Dirección: Marco Bechis. Producción: Amadeo Pagani; Enrique Piñeyro; Eric Heumann. Protagonistas: Antonella Costa; Carlos Echevarria; Enrique Piñeyro; Dominique Sanda; Pablo Razuk. Guión: Lara Fremder; Marco Bechis. Música: Jacques Lederlin. Sonido: Guido Berenblum. Fotografía: Ramiro Aisenson. Montaje: Jacopo Quadri. Escenografía: Rómulo Abad. Género: Drama. Argentina, 1999. 98 min.

GUERRERO DEL RÍO, Eduardo. Un texto conmovedor: novelista de profesión. La Segunda, p. 47, 14 nov. 1996.

HISTORIA oficial (La). Dirección: Luis Puenzo. Guión: Aída Bortnik; Luis Puenzo. Reparto: Héctor Alterio; Norma Aleandro; Chela Ruiz; Chunchuna Villafañe; Hugo Arana; Patricio Contreras; Guillermo Battaglia; Leal Rey. Música: Atilio Stampone. Fotografía: Félix Monti. Argentina: Historias Cinematográfica; Progress Communications, 1985. 110 min.

KORNBLUH, P. Pinochet: los servicios secretos. Barcelona: Crítica, 2004. 
LEY de Herodes (La). Producción: Luis Estrada. Guión: Luis Estrada, Jaime Sampietro, Fernando León, Vicente Leñero. Música: Santiago Ojeda. Fotografía: Norman Christianson. Protagonistas: Damián Alcázar; Pedro Armendáriz Jr.; Isela Vega; Ernesto Gómez Cruz; Evangelina Sosa. México: Bandidos Films; Videomax, 1999. 123 min.

NOCHE de los lápices (La). Dirección: Héctor Olivera. Guión: Daniel Kon; Héctor Olivera. Reparto: Adriana Salonia; Alejo García Pintos; Alfonso De Grazia; Héctor Bidonde; José María Monje; Leonardo Sbaraglia; Lorenzo Quinteros; Manuel Callau; Pablo Machado; Pablo Novak; Tina Serrano; Vita Escardó. Música: José Luis Castiñeira de Dios. Argentina, 1986. Color (Eastmancolor), 105 min.

PEREZ MURILLO, M. D.; FERNÁNDEZ FERNÁNDEZ, D. (Coords.). La memoria filmada: América Latina a través de su cine. Madrid: IEPALA, 2002.

. La memoria filmada: historia sociopolítica de América Latina a través de su cine. Madrid: IEPALA, 2009.

QUE é isso companheiro? (O). Dirección: Bruno Barreto. Producción: Lucy Barreto; Luiz Carlos Barreto. Guión: Leopoldo Serran; Fernando Gabeira (libro). Reparto: Fernanda Torres; Pedro Cardoso; Alan Arkin; Luiz Fernando Guimarães; Cláudia Abreu. Género: Drama. Música: Stewart Copeland. Fotografía: Félix Monti. Montaje: Isabelle Rathery. Brasil: RioFilme; Miramax (EUA), 1997. 110 min.

RANALLETTI, Mario. La construcción del relato de la historia argentina en el cine, 1983-1989. Film-História, Barcelona, v. 9, n. 1, 1999.

RIERA, Carme. Cap al cel obert. Barcelona: Destino, 2000.

SALVADOR Allende. Dirección: Patricio Guzmán. Guión: Andrea Guzmán. Montaje: Claudio Martínez. Imagen: Julia Muñoz; Patricio Guzmán. Sonido: Alvaro Silva Wuth. Música: Jorge Arriagada. Productor delegado: Jacques Bidou. Chile: JBA, 2004. Productions Soporte de rodaje: DVCam. Soporte definitivo: 35 mm (1.85), DVD y Beta Pal.

SAND, Shlomo. El siglo XX en pantalla. Barcelona: Crítica, 2005.

TRAVERSO, E. Els usos del passat: historia, memòria i politica. València: PUV, 2006.

VÁSQUEZ, David. El cine como registro de una sociedad que cambia. In: RIQUELME, A. (Ed.). Chile: Historia y presente: una visión interdisciplinaria. Santiago: Instituto de Historia de la PUC, 1995. 
Joan del Alcàzar, doctor en Historia por la Universitat de València, es profesor titular en el Departamento de Historia Contemporánea de esta institución y dedica desde hace años su actividad investigadora a la historia de América Latina en general y a la de Chile en particular.

jalcazar@uv.es

Recebido em 31 de julho de 2012.

Aprovado em 31 de agosto de 2012. 